\title{
Relaxing Response to Transmural Stimulation of Isolated Taenia Coli of the Chimpanzee and Pig
}

\author{
Akira Rikimaru \\ Department of Applied Physiology, * Tohoku University \\ School of Medicine, Sendai
}

Rrkmaro, A. Relaxing Response to Transmural Stimulation of Isolated Taenia Coli of the Chimpanzee and Pig. Tohoku J. exp. Med, 1971, 103(1), 115-116The transmural stimulation caused relaxation of atropinized taenia strip from chimpanzee and pig. This relaxing response was not blocked by adrenergic blocking agent (bretylium) but abolished by tetrodotoxin. From this fact, it seems reasonable to assume the presence of non-adrenergic inhibitory nerve system in taeniae of the chimpanzee and pig.—_ relaxing response; non-adrenergic inhibitory nerve system

Traditional concepts about the inhibitory regulation of the gastrointestinal motility have recently been shaken by cumulative physiological and phamacological evidence suggesting the presence of non-adrenergic inhibitory neurons. Paton and Vane (1963) first described the fact that the relaxing responses elicited by transmural stimulation in stomachs of various animals were resistant to adrenergic nueron blocking agents. They were, however, of the opinion that these relaxing responses might be due to the stimulation of sympathetic adrenergic nerves at the site peripheral to the point of action of the blocking agents. Burnstock et al. (1964, 1966) observed the same phenomenon in guinea-pig taenia coli and suggested the presence of non-adrenergic inhibitory neurons in the intestinal wall.

The purpose of the present study is to examine whether such non-adrenergic inhibitory neurons exist in other intestinal preparations. The isolated taenia preparations from chimpanzee and pig were used and the tension response elicited by transmural stimulation with square-wave pulses was recorded isometrically. In the chimpanzee taenia coli, the relaxation was produced maximally by trains of pulses ( $1.0 \mathrm{msec}$ duration) at frequencies between 5 and 10 pulses/sec which is sufficient to excite the intrinsic nervous elements selectively. The relaxing response of the chimpanzee taenia coli was not blocked by bretylium up to the concentration of $5 \times 10^{-5} \mathrm{~g} / \mathrm{ml}$ (Fig. 1). This concentration of bretylium is sufficient to block the sympathetic adrenergic nerves. The bretylium-resistant relaxing response was entirely abolished after addition of tetrodotoxin, a wellknown neurotoxin (Kao 1966). This result may be taken as evidence that the

Received for publication, October 14, 1970.

* Director: Prof. T. Suzuki. 


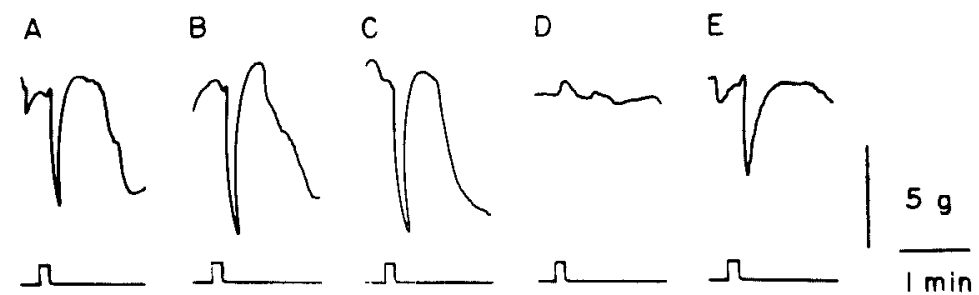

Fig. 1. Relaxing response of chimpanzee taenia coli to the transmural stimulation. A: before atropine. B: in the presence of atropine $10^{-7} \mathrm{~g} / \mathrm{ml}$. C: in the presence of atropine $10^{-7} \mathrm{~g} / \mathrm{ml}$ and bretylium $10^{-7} \mathrm{~g} / \mathrm{ml}$. D: in the presence of atropine $10^{-7} \mathrm{~g} / \mathrm{ml}$ and tetrodotoxin $10^{-8} \mathrm{~g} / \mathrm{ml}$. The relaxing response was abolished. E: after washing tetrodotoxin out of the bath. Lower traces indicate the period of electrical stimulation (at 10 pulses/sec for 5 seconds).

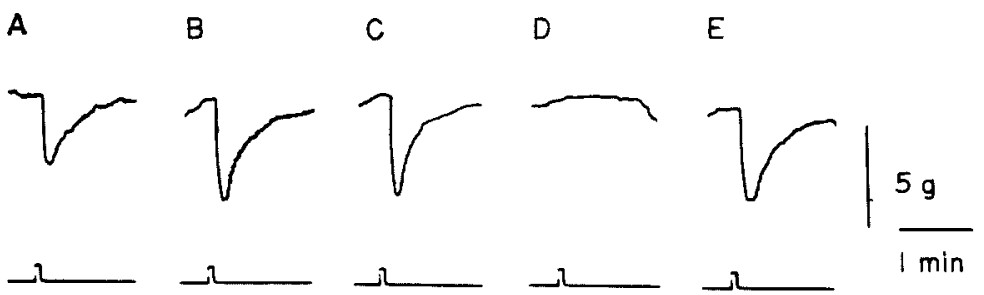

Fig. 2. Rexlaing response of pig taenia coli to the transmural stimulation. A: before atropine. B: in the presence of atropine $10^{-7} \mathrm{~g} / \mathrm{ml}$. C: in the presence of atropine $10^{-7}$ $\mathrm{g} / \mathrm{ml}$ and bretylium $5 \times 10^{-5} \mathrm{~g} / \mathrm{ml}$. D: in the presence of atropine $10^{-7} \mathrm{~g} / \mathrm{ml}$ and tetrodotoxin $10^{-8} \mathrm{~g} / \mathrm{ml}$. The relaxing response was abolished. E: after washing tetrodotoxin out of the bath. Lower traces indicate the period of electrical stimulation (at $10 \mathrm{pulses} / \mathrm{sec}$ for 10 seconds).

relaxing response is due to stimulation of the intramural nerve fibers, and not due to direct inhibition of the smooth muscle cell activity. The result with the pig taenia coli was essentially the same as that obtained from the experiments on chimpanzee. The relaxation was resistant to bretylium but blocked by tetrodotoxin (Fig. 2).

It was concluded from these results that non-adrenergic inhibitory neurons may exist in the taenia coli of chimpanzee and pig.

\section{References}

1) Burnstock, G., Campbell, G., Bennett, M. \& Holman, M.E. Innervation of the guineapig taenia-coli: are there intrinsic inhibitory nerves which are distinct from sympathetic nerves ? Int. J. Neuropharmacol., 1964, 3, 163-166.

2) Burnstock, G., Campbell, G. \& Rand, M.J. The inhibitory innervation of the taenia of the guinea-pig caecum. J. Physiol. (Lond.), 1966, 182, 504-526.

3) Kao, C.Y. Tetrodotoxin, saxitoxin and their significance in the study of excitation phenomena. Pharmacol. Rex., 1966, 18, 997-1049.

1) Paton, W.D.M. \& Vane, J.R. An analysis of the responses of the isolated stomach to electrical stimulation and to druge. J. Physiol. (Lond.), 1963, 165, 10-46. 